\title{
A Fine Story
}

Author(s): J. S.

Source: All Ireland Review, Vol. 3, No. 39 (Nov. 29, 1902), p. 637

Published by: All Ireland Review

Stable URL: http://www.jstor.org/stable/20546314

Accessed: 23-06-2016 15:45 UTC

Your use of the JSTOR archive indicates your acceptance of the Terms \& Conditions of Use, available at

http://about.jstor.org/terms

JSTOR is a not-for-profit service that helps scholars, researchers, and students discover, use, and build upon a wide range of content in a trusted

digital archive. We use information technology and tools to increase productivity and facilitate new forms of scholarship. For more information about JSTOR, please contact support@jstor.org.

All Ireland Review is collaborating with JSTOR to digitize, preserve and extend access to All Ireland Review 
kicked out by other men. . Sometimes the new-comers killed them all off. At other times they made them hewers of wood and drawers of water-treating them as the first-comers treated the horses and donkeys who were allowed to live on condition that they worked for their masters. Is there an acre of Irish land now in the hands cf the descendants of the first settlers in Ireland? I doubt it.

But the second settlers were similarly dealt with, and very often the third, fourth and fifth settlers. It was always the same good old plan-."That they should take who have the power, and they should keep who can." Since times became more peaceful, however, instead of taking the land, men who wanted it began to buy it from those who were in possession; and in Ireland, at all events, these sales were carried on through the State, who guaranteed to the purchaser all the title that the State could give.

The land of the country never belonged to the people of the country in the sense that it was commonage or divided equally among all the people. The only sense in which it now belongs to the people is that the Legis lature is omnipotent with respect to it, and that under our present system the Legislature represents the people. It can sell land, guarantee the title and take the land back again. This would be dishonest in an individual, but the Legislature, like a corporation, has neither a body to be kicked nor a soul to be - But it is only through the Legislature that the people can claim the land as theirs. All claims to land rest on the fact that the claimant's ancestor took it by force, or bought it from somebody whose ancestors took it by force. A tenant, indeed, may not, strictly speaking, have bought it, but he came in under a contract of the same nature. . He hired it ; or else having been deprived of the ownership by force, he agreed to pay the new owner for continued occupation.

Please descend from generalities to particulars. The land of the country belongs to the people of the country You and I belong to the people of the country. How much land and of what guality falls to each of us by right? or is the mode of distributing the land of the country among the people of the country to be arbitrarily fixed by the Legislature? I could write more, but this is fixed by the Legislature? I could write more, but this
enough for the present. - Truly yours,

[DEAR X.-In his great work, "Liberty and Democracy,' Mr. Lecky tells us that the State has a perfect right to take land for public purposes, paying the owner a just compensation. I would only take from individuals, ver carefully and scrupulously, what the country really needs, and then give Man access to that bit of Earth so acquired under conditions justifiable to Reason and the national weal.

I would not give it to clever business men for commercial exploitation. Not a square foot of it.

Have you considered my question:-_"We have all a natural right to a bit of Ireland; six feet by three; rent free; when we are dead! Have we any natural right to a little of it; if we pay rent for it, and work upon it, while we are alive?"-ED.]

$$
*_{*}^{*}
$$

THE MADNESS OF ADNUAILL

A hound of the hounds of Finn, whose name was Adnuaill, came forth of a day out of the camp of the Fianna on the Hill of Allen, and stood on the slope of the Hill, and bayed, looking to the North. And after that he went three times round Ireland baying, and stopped at last at the river-ford called Ath-an-Con, in Tir-Connall, and there, baying terribly and still looking to the North, he fell dead.

And they buried him there, and set up his stone over him, with his name, in Ogham, on it-_"Adnuaill here"!

And what Adnuaill saw, and what urged upon that wild course is known to no man. Adnuaill was the third greatest of Finn's hounds-coming after Bran and Ceolân.

\section{PIANOS " rhoo vars PIANOS. "ssstem." HARMONIUMS. socond-hand AMERICAN ORGANS. a EASY TERMS. - LBERAL DISCOUNTS.}

THE MOCK LER FAMILY (CO. TIPPERARY).

Sir.-On the low spur thrown eastward by Slievenamon, from its northern extremity there is a rocky peak rising about 900 feet abore sea level, called Carrigmoclear. This name becomes interesting if (as may, perhaps, be done without assuming too much license) it is spelled Cappais (mannanaan) maclip. (I am not sure that this form is quite correct). The nome is sometimes "anglicised" Mount Mockler." The family name, Mockler, (long o, sometimes written "Moclair,") was formerly very prevalent in this locality, and there is a village called Grangemockler, half a mile southward from Carrigmoclear. The genealogical map, published by the "Gael "periodical, locates the family or clan of Mockler here. The circumstances seem to indicate that this place was a Dedannan stronghold, and that the family of Mockler is of Dannaanian origin. I do not know how the name, Mockler, stands in the genealogies, and I have at present no means of knowing. The name is now widely spread through south Tipperary and Waterford, and many of its bearers show, what I believe are, strong Dannaanian points. I am aware that "A.I. R." does not believe in the Dannaanian "flesh and blood theory," but that cherub will find it difficult to explain away the cairns of the Moyturas. Carrigmoclear is overhung by that portion of Slievenamon which is identified in legend with the Dedannan. The derivation of the name of the mountain from the family name may possibly be a reversal of the true etymological order. This matter may prove a mare's nest, yet it may contain a clue to the unravelling of a perplexed question. SheEgouna.

$$
\text { ORIGIN OF A NAME. }
$$

DEAR Sir,-Could you tell me is Durnin an Irish name? If it is, what part of the country did they belong to. Also, what is the Gaelic form of the name-mire le mear, DuRnin.

[Dear Mr. D.-Yes, I feel sure it is as Irish as my own, but trust some learned reader will tell us all about it. It is not historic, though the sept was no doubt derived from one of the great historic septs. All our minor families seem to be derivatives from the great.-ED.]

\section{A FINE" STORY.}

DEAR A.I.R.-Have you read a novel (historical, of Siege of Derry) called "A Man's Foes?" and if so, do you know who the author $H$. Strain may be, and why H. S. has not written any more? I have read a good many novels in my time, but I do not remember any "Portrait of a Lady," that for artistic finish, quite comes up to Mistress Hamilton as portrayed in " A Man's Foes," not in George Elliott, or Thackeray, or Scott, or Jane Austen, or anywhere that I know of. At least that is my opinion. If H. Strain be Irish, as I suppose, I think we should blow our trumpet a little about this. I. S.

[Dear J. S.-This is high praise, indeed, and I suspect you are right.

I read a good historical novel lately, not "Nessa," but Noehme," by Baring Gould. The time is that of Joan of Arc-all about the small captains of military companies who then preyed upon France.

It occurred to me that an Irish historian of the 14th and 15th centuries might get many hints and ideas from it: our social condition being not so dissimilar.

I am writing for a "Man's Foes."-Ed.]

\section{TO SUBS"CRIBERS.}

IAST week some copies were accidentally above the $2 \mathrm{oz}$ which "the wicked Minister" allows the King to carry for $\frac{1}{2} \mathrm{~d}$., and subscribers had to pay the postman an extra penny on delivery. This, we trust, will be the last time on which we shall have to complain of that gentleman who has given A. I. R. so many an uneasy hour with his absurd rules, made seemingly with the object of killing thought by taxation.-ED. 